\title{
How close they were to success
}

\author{
Melissa Koci, BS, and Chadrick E. Denlinger, MD
}

From the Division of Cardiothoracic Surgery, Medical University of South Carolina, Charleston, SC.

Disclosures: Authors have nothing to disclose with regard to commercial support.

Received for publication Feb 22, 2018; accepted for publication Feb 22, 2018; available ahead of print March 17, 2018.

Address for reprints: Chadrick E. Denlinger, MD, Medical University of South Carolina, 114 Doughty St, Suite

201, Charleston, SC 29425 (E-mail: denlinge@musc.edu).

J Thorac Cardiovasc Surg 2018;156:918-9

$0022-5223 / \$ 36.00$

Copyright $\subset 2018$ by The American Association for Thoracic Surgery

https://doi.org/10.1016/j.jtcvs.2018.02.056

The number of lung transplants performed worldwide continues to slowly increase, and the greatest limiting factor remains the availability of transplantable organs. The concern for primary graft dysfunction, which occurs in at least $25 \%$ of all lung transplants, further restricts organ acceptance when donors do not meet ideal donor criteria. Ex vivo lung perfusion (EVLP) has opened the door for the provisional use of marginal lung donors given the ability to assess pulmonary and vascular compliance before committing a patient to transplantation. This has led to the successful use of organs that would have otherwise been turned down. Preclinical work is now pushing the boundaries of EVLP beyond the simple assessment of pulmonary function to rehabilitation of marginal lungs before transplantation.

Mehaffey and colleagues ${ }^{2}$ explored new means of improving the vascular integrity and pulmonary function in an early preclinical murine model of EVLP. The authors suggest that supplementing the standard perfusate with both sphingosine-1-phosphate (S1P) and an intracellular sphingosine-1-kinase inhibitor (SphKi) enhances the extracellular/intracellular S1P gradient that reduces vascular permeability and improves pulmonary function. These interesting data need to be further explored.

The most dramatic physiologic improvement observed was lung compliance in the group that was perfused with the solution containing both S1P and SphKi. Although significant overlap was noted in the absolute lung compliance values of each of the 4 treatment groups, the relative change reported was far greater in the group perfused with Steen + S1P + SphKi compared with any of the other 3 groups. We look forward to further work showing this improved pulmonary compliance that will hopefully include large animal models demonstrating improved graft performance after transplantation.

The current study adds to a growing body of literature exploring avenues of lung reconditioning while performing EVLP. In other preclinical studies around the world, the use of a wide spectrum of agents including drugs, vectordelivered genes, and cellular therapy has been described.

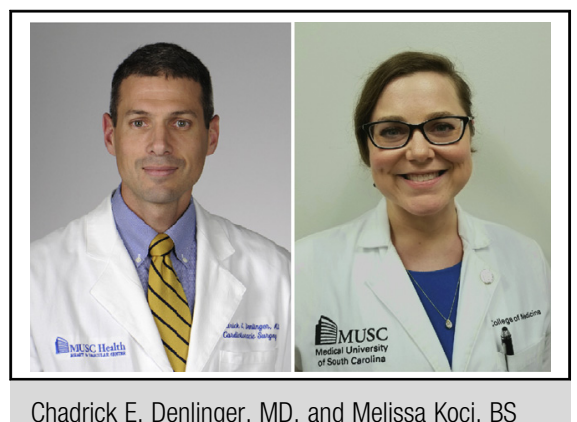

Chadrick E. Denlinger, MD, and Melissa Koci, BS

Central Message

Ongoing exploration of EVLP therapeutic adjuncts will identify agents that improve pulmonary function and expand the donor pool.

See Article page 910.

Some examples of previous studies include the Charlottesville group, which previously demonstrated improved lung compliance in a large animal model when pharmacologic inhibition of the adenosine A2B receptor is added during EVLP. ${ }^{3}$ The Toronto group showed that virally delivered interleukin-10 during ex vivo perfusion diminished pulmonary inflammation and improved oxygenation 7 days after transplantation in a porcine model. These differences were noted despite the fact that the initial oxygenation after transplant of the interleukin-10 group was no different compared with a control group. ${ }^{4}$ Mesenchymal stem cells also have been explored as an experimental therapeutic adjunct for EVLP and have been shown to improve lung compliance. ${ }^{5}$

Therapeutic interventions investigated for lungs on EVLP have been widely disparate and seemingly unrelated with the exception of the shared goals of improving pulmonary function and minimizing the risk for primary graft dysfunction. Each intervention has resulted in less than perfect success, but we will not give up. As Thomas Edison said, "Many of life's failures are people who did not realize how close they were to success when they gave up."

\section{References}

1. Cypel M, Yeung JC, Machuca T, Chen M, Singer LG, Yasufuku K, et al. Experience with the first 50 ex vivo lung perfusions in clinical transplantation. J Thorac Cardiovasc Surg. 2012;144:1200-6.

2. Mehaffey JH, Charles EJ, Narahari MD, et al. Increasing circulating sphingosine1-phosphate attenuates lung injury during ex vivo lung perfusion. J Thorac Cardiovasc Surg. 2018;156:910-7. 
3. Charles EJ, Mehaffey JH, Sharma AK, Zhao Y, Stoler MH, Isbell JM, et al. Lungs donated after circulatory death and prolonged warm ischemia are transplanted successfully after enhanced ex vivo lung perfusion using adenosine A2B receptor antagonism. J Thorac Cardiovasc Surg. 2017;154:1811-20.

4. Machuca TN, Cypel M, Bonato R, Yeung JC, Chun YM, Juvet S, et al. Safety and efficacy of ex vivo donor lung adenovarial IL-10 gene therapy in large animal lung transplant survival model. Hum Gene Ther. 2017;28: 757-65.

5. Martens A, Ordies S, Vanaudenaerde BM, Verleden SE, Vos R, Van Raemdonck DE, et al. Immunoregulatory effects of multipotent adult progenitor cells in a porcine ex vivo lung perfusion model. Stem Cell Res Ther. 2017;8:159. 